\title{
Linking Innovation Measurement to an Implementation Framework: A Case Study of a Financial Services Organization at the Front End of Innovation
}

\author{
C. Brooke Dobni \\ dobni@edwards.usask.ca | Edwards School of Business, University of Saskatchewan, Saskatoon, Canada, \\ S7N 5A7 \\ Mark Klassen \\ mklassen@edwards.usask.ca | Edwards School of Business, University of Saskatchewan, Saskatoon, \\ Canada
}

\begin{abstract}
Many organizations find themselves at the "front end of innovation", that is, they know they need to do something, but they are not quite sure what to do. Through our research, we have learned much more about the practice and implementation of innovation. For example, we have discovered that innovation is most successful if there is leadership support for a culture of innovation combined with systematic approaches to embed and reinforce innovative behaviours. This article outlines a case study of an organization in the financial services industry who began their innovation journey a number of years ago, and reports on the progress of a sustained and deliberate approach. This research highlights the relationship between an innovation cultural assessment model and its utilization as a framework to manage the implementation of activities to support the development of an innovation approach in a context specific scenario. A case study methodology was adopted that utilized an innovation culture model as a measurement tool. By actively observing the organization, including two cultural assessments over a 4-year period, the findings indicate that an innovation assessment model is useful as an approach to advance the innovation agenda in the organization. In this sense, the research findings are of interest to academics looking to conceptualize a broader implementation framework that is closely associated to the innovation measure associated with the organization. As well, practitioners looking to advance their innovation platforms will find the framework useful as they plan initiatives aimed at advancing their innovation agendas.
\end{abstract}

Keywords. Innovation culture management, Implementation of innovation, Strategy.

Cite paper as: Dobni, C., Klassen, M. (2018). Linking Innovation Measurement to an Implementation Framework: A Case Study of a Financial Services Organization at the Front End of Innovation, Journal of Innovation Management, www.open-jim.org, 6(1), 80-110. http://hdl.handle.net/10216/111571 


\section{Introduction}

Innovation is believed to be a key differentiator and a necessity in achieving competitive advantage (Amit and Schoemaker, 1993; Prahalad and Hamel, 1990). As a result, there has been a significant interest in innovation implementation, particularly with respect to innovation culture and its effect on strategy and financial performance (Naranjo Valencia et. al, 2010; Aas and Pedersen, 2011; Christensen and Raynor, 2003; Govindarajan and Trimble, 2005; Hamel, 2002; Hammer, 2004; Senge and Carstedt, 2001).

However, many organizations are at the front end of innovation, and our experience as both academics and management consultants has led us to conclude that many organizations know they need something, but are not quite sure what. As a result, many efforts to develop an innovation approach are either piecemeal, under resourced, or run off 'the side of the desk.' This leads to a lack of sustained effort, and often, frustration and failure.

As the appetite for innovation in organizations gains momentum, research on how to best approach it continues. Research on innovation in the financial services is no different. Specific aspects of innovation in the financial services industry have been researched, such as regulation (Nekrep, 2013), competition (Bos et al., 2013; Aghion and Griffith, 2005), implementation models (Bukowitz, 2013), leadership (Johne and Harborne, 2003; Harborne and Johne, 2002) and service and product innovation (Vermeulen and Dankbaar, 2002; Ozdemir and Trott, 2009).

We also know that there is a linkage between innovation and performance. We now have research to support the relationship between innovation and performance in organizations (Nambisan, 2013; Wong, 2012; Jimenez-Jimenez and Sanz-Valle, 2011; Dobni, 2010; Dobni, 2011; Dobni and Klassen, 2015). Simply stated, innovative organizations - regardless of the industry generally perform better.

Our interest is in connecting two important streams of innovation: innovation culture measurement and innovation implementation frameworks. By linking these two streams, we address a notable gap in the literature. For example, innovation culture measurement models exist (Dobni, 2008; Wang and Ahmed, 2004) but have not yet been fully used to impart an implementation framework. Further complicating the issue is that not one size fits all. It seems that every organization wants or needs slightly different approaches; approaches which are tempered by the competitive context, the nature of the industry, and internal support and resources for innovation. Thus, implementation of innovation is highly contextual and depends on each organization's internal and external environment (Ortt \& van der Duin, 2008).

The research objective is to understand whether an innovation culture measurement model can be used as an implementation framework in the context of a financial services industry. The innovation culture assessment model utilized in this study was the (Dobni 2008) model. It assesses innovation culture by measuring twelve drivers (determinants) of innovation and categorizes the drivers into the following four dimensions: leadership, resources, knowledge management, and process. These four dimensions were used as an implementation framework by the organization profiled in the case study to advance their implementation agenda. Our view is that using an implementation framework based on a measurement tool is pragmatic, practical and logical based on the simple premise of, "what gets measured gets done". This notion is similar to the concept of measuring strategy through a balanced scorecard (Kaplan and Norton, 1992) and then subse- 
quently developing initiatives to advance the strategic intent. The scorecard not only provides a benchmark measure to assess current state and progress, but focuses the implementation activities to those that have the most impact on strategy. The financial services industry provides a relevant innovative context given the nature of change in industry due to phenomenon such as fintech (Schueffel, 2016). Although our research has application across industries, organizations that have challenging and changing context, such as the financial services industry, will find the application particularly relevant.

This article discusses the relative literature related to innovation definitions, performance, innovation culture measurement, and the context of innovation in the financial services industry. The intent of this review is to highlight the notable gaps in the literature as well as to inform our case study. A methodological discussion of the research approach and narration of the case study findings follows. We conclude with a discussion on management considerations and final thoughts of the case study related to using an innovation culture assessment model as an implementation framework.

\section{Theoretical Perspectives}

\subsection{Issues of Definition}

Research has defined innovation in a variety of ways. Often the definition depends on the nature of the research and context of the study. Many definitions infer the introduction of a behaviour or idea as a central theme in explaining innovation (Cordero et al., 2013; Jimenez-Jimenez \& Sanz-Valle, 2011). Employee actions that are a result of creativity or change have been associated as an innovation outcome. Examples of this include ideas surrounding new product/services or modifications to existing ones, restructuring or cost savings initiatives, better communication practices, new techniques to solve old problems, or unique employee responses to unscripted situations (Martins and Terblanche, 2003; Robbins, 1996; West \& Farr, 1990). Other definitions (Hamel, 2006; Christenson, 1997) suggest that innovation is contextual, and the determination of whether or not activities or behaviors in an organization can be regarded as innovative will be constrained by this context.

The determinants of innovation include leadership (Mumford and Licuanan, 2004; Crossland and Hambrick, 2007), strategy (Miller and Friesen, 1982; Tipping and Zeffren, 1995; Miles and Snow, 1978), organizational structure (Damanpour, 1991; West et. al, 1998), portfolio and project management (Cooper et al., 1999) and learning and knowledge management tools (Crossan et al., 1999; Alexy et. al, 2013). This list is by no means exhaustive but illustrates the breadth of the research field related to the implementation of innovation. Attempts to synthesize this literature have been completed, but have resulted in a general conclusion that the research is fragmented and often narrowly focused (Crossan and Apaydin, 2010).

We have also concluded that the definition is context specific and ranges from uni-dimensional, for example, the amount of budget allocated to research and development, or the number of new patents registered on an annual basis, to multi-dimensional and disruptive, which materially alter industries or create entirely new industries. These would include products/services innovation, process innovation, technological innovation, and business model innovation. 
It is also important to note that innovation is process-oriented and culture-based (Drucker, 1991; Hellriegel et al., 1998; Robbins, 1996). Given our focus on understanding an innovation framework, for definitional purposes, we adopt the broad definition of (West \& Farr 1990, p. 7) whom define innovation as "the intentional introduction and application within a role, group or organization of ideas, processes, products or procedures, new to the relevant unit of adoption, designed to significantly benefit the individual, the group, organization or wider society."

There is no question, that innovation is multi-dimensional, multi-disciplinary, complex and is impacted by many factors (Baregheh et al, 2009; Kline and Rosenburg, 2010; Van de Ven, 1986) and in this vein, is similar to culture. (Schein 1984), points to culture as the prerequisite to innovation in organizations. The prevailing conclusion is that a focused and aligned culture appears to be critical to the success of any organization (Ahmed, 1998; Martins and Terblance, 2003; McLean, 2005; Mumford, 2000), and if you can manage the context, then you can affect culture to direct desired behaviors. This is the premise of behavior-action-outcome modelling (Dobni and Luffman, 2003) which can be applied to innovation activities.

Drawing from our practical experience, many organizations simply do not know where to start that is one of the issues with being at the front end of innovation. Organizations need a point of reference, and we propose that the measurement of innovation culture provides organizations with a benchmark to assess the current status of innovation. It also provides a platform to plan how they can improve innovation culture. This linkage provides the basis of utilizing the innovation culture measurement model as a framework for innovation implementation going forward. The following model articulates our scope of inquiry:

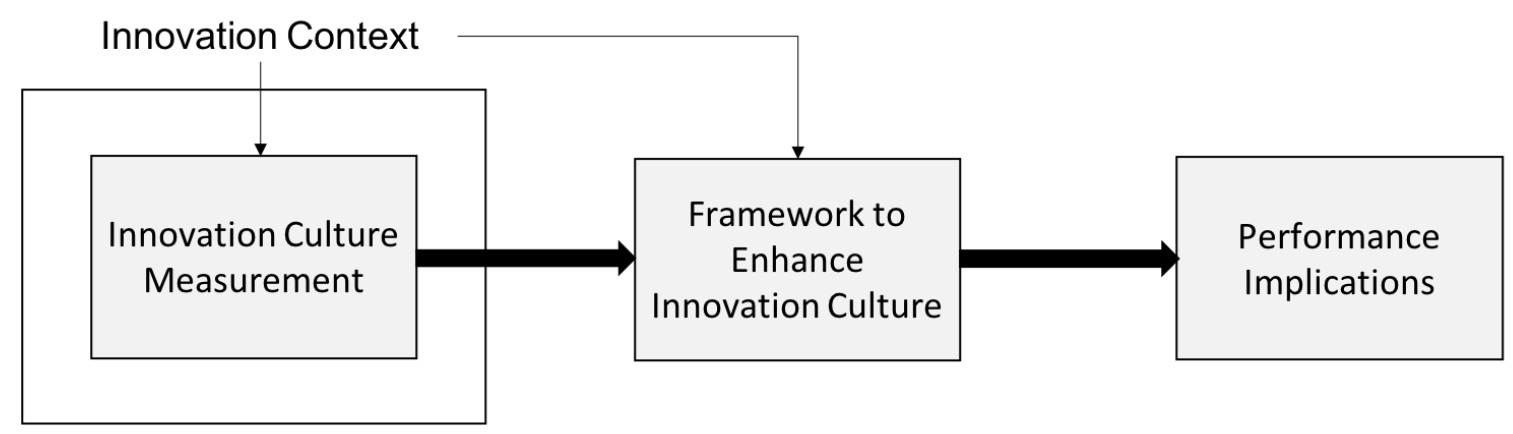

Actual Innovation State $\longrightarrow$ Desired Innovation State

Fig. 1. Innovation Scope of Inquiry

\subsection{Innovation and Performance}

Academic research in addition to large global consulting firm studies suggest increasing the innovative capabilities in organizations will be the linchpin to increasing profitability and growth in organizations, particularly in an era where productive lives of strategy shortens and competitive boundaries blur. These studies suggest that innovation management has potential to improve growth and profits. A study by Arthur D. Little (Thuriaux-Aleman et al., 2013) concluded the top quartile innovation performers obtain a $13 \%$ higher profit than the average performers. A 
similar consulting firm study found organizations with significant alignment between their core business and innovation strategies outperform their competitors. The study noted a $40 \%$ higher operating income growth over a three-year period and 100\% higher shareholder return (Jaruzelski et al., 2014). The association between innovation and performance has also been reported by academics in a breadth of studies (Calantone et al., 2002; Cooper, 2000; Klomp and van Leeuwen, 2001; Li and Calantone, 1998). An innovation - performance study more closely aligned to this research is (Dobni 2011) which surmised that an innovation orientation is related to organizational performance overall. The research concluded that high innovating firms had a positive relationship with the top line growth, customer satisfaction, bottom line growth, and profitability. Alternatively, organizations possessing low innovation orientations had significant negative correlations with return on investment, overall firm performance and the overall enterprise value (Dobni and Klassen, 2015).

(Audretsch 1995) found that new entrant firms that survived in highly innovative industries outperformed other industry players. New firms that were not able to adapt had a significantly lower rate of survival. Knowledge management capabilities, a key driver of the innovation model in this research, allows resources to be used more efficiently which leads to enhanced innovation and performance (Darroch, 2005). (Jimenez-Jimenez \& Sanz-Valle 2011) found organizational learning and innovation positively impact performance and that organizational learning impacted innovation. Open innovation, through cooperation with and information sourcing from competitors, positively influences innovation performance (Mention and Asikainen, 2012). Similar framing of the literature as it pertains to intellectual capital, innovation and performance, has been researched as well (Mention, 2012).

In the end, although most companies viewed innovation as extremely important, as high as $85 \%$, only $15 \%$ of organizations considered themselves to be successful at creating an innovation environment (Thuriaux-Aleman et al., 2013). Creating an innovative environment is predicated on the organizations ability to implement an innovation agenda. Enhanced performance is only realized if an innovation culture is created and sustained.

\subsection{Innovation Culture Measurement}

Research has been conclusive in establishing the key role culture plays in innovation (Ahmed, 1998; Dobni, 2008; Higgins and Mcallaster, 2002; Jassawalla and Sashittal, 2002; Lau and Ngo, 2004). Organizational culture is defined as the value, beliefs and hidden assumptions members have in common (Cameron and Quinn, 1999; Denison, 1990; Miron et. al, 2004). (Hartman 2006) explains that culture stimulates innovation behaviour and commitment to innovation amongst the employees of organizations.

Two streams of measurement research have developed related to measuring innovation culture. One stream measures culture in a more traditional sense using established culture typology instruments (Kets De Vries and Miller, 1986; Reigle, 2001; Wallach, 1983) and then assessing which types of culture enhance or inhibit innovation. For example, (Valencia et. al 2010) used the Competing Values Framework (Cameron and Quinn, 1999) to determine that ad hocratic (flexible and unstructured) cultures enhance the development of new products and services, whereas hierarchical cultures inhibit product innovation. Another stream of research (Dobni, 2008; Wang 
and Ahmed, 2004) argue that the determinants of innovation (e.g. leadership, structure, process, organizational learning) are in fact a proxy of the innovation activity in an organization. The determinants affect employees through socialization and coordination (Chatman and Jehn, 1994; Martens and Terblance, 2003; Valencia et. al, 2010) and therefore a measurement of the determinants provides a view of the organization's innovation culture. Although both streams investigate the relationship between culture and innovation, they do not extend to our inquiry of understanding whether the measurement models can be used as an implementation framework.

\subsection{Innovation Context in the Financial Services Industry}

The financial service industry provides an excellent field of scholarly investigation because it is continually being subject to changing context. (Ortt \& van der Duin 2008) have categorized the context phenomenon related to innovation as contextual innovation (van der Duin et. al, 2014). Early contingency theorists (Burns and Stalker, 1961; Woodward, 1965; Lawrence and Lorsch, 1967; Thompson, 1967), advanced the notion that organizational effectiveness resulted from fitting characteristics of the organizations such as its structure, to the contingencies that impact the situation of the organization (Donaldson, 2001). Aggregation of contingency theory literature in management fields has enabled scholars to piece together general propositions, such as the relationship between size, strategy, external environment, structure, industry and how organizations execute their business through their technology, processes, and management programs (Chenhall, 2003). With respect to this research, context is important as it will impact the organization's innovation culture, as well as their decisions on how to best execute their innovation agendas. Our belief is that measuring innovation culture will allow organizations to assess the current innovation state and then utilize the measurement categories as a framework to achieve the innovation culture desired state. At any rate, choices of implementation tools will ultimately be impacted by context.

Although the definitions of "fintech" are numerous, see (Schueffel, 2016) for a thorough summary, there is a consensus that new technologies have shaped innovation within the financial services industry (Arner et al., 2015) and will continue to be disruptive compelling change in the future (Schneider et al., 2016; Schueffel, 2016). Innovation research in the financial services industry suggests that the innovation framework in this study may be informative to piece together research findings and commentary. Innovation to develop new products and services is critical for financial services organizations (Drew, 1995) but difficult and complex to manage and measure strategically (Ittner et al., 2003). (Akamavi 2005) found significant research gaps in recognizing the importance of customers and supporting operational units in developing new financial services products. (Vermeulen 2004, Vermeulen 2005) identified barriers to product innovation in the financial services industry: functionally departmentalized structures, limited use of development tools, conservative organization culture, constraining information technology, resources, project based work and incentives. These studies add validity to the relevance of the innovation framework used in this research. The barriers identified by (Vermeulen 2004, Vermeulen 2005), new product development (Drew, 1995), and measurement issues (Ittner et al., 2003) are incorporated into the (Dobni 2008) model though the measurement of innovation determinants and the subsequent innovation activities implemented to improve the innovation score. (Gallouj \& Savona 2009) suggest an innovation research agenda for service firms that is 
more integrative conceptualized around a typology of innovation magnitude (e.g. radical versus incremental innovation). The innovation framework in this study is aligned to this thinking by being comprehensive in the determinants and allowing a measurement discussion to determine whether an organization is pursuing radical innovation (e.g. a $20-25 \%$ increase in their innovation score or an incremental 5-10\% increase).

To elaborate on the context for the financial services industry we have adapted the current state analysis of (Dobni 2006) illustrated in Figure 2. More recent financial services literature suggests the analysis categories are still relevant in today's financial services industry and in particular, research oriented towards innovation. Deregulation is still an important contextual factor impacting the financial services industry, thus driving the financial services industry to be more innovative (Bos et. al, 2013). (Nejad \& Estelami 2012) argue deregulation resulting from the Bank of Modernization Act of 1999 in the United States continues to impact the financial services industry through the expansion of products that insurance firms, banks, and other financial services providers can offer. The rate of new products and services has been increasing as well to the point that the number of new products introduced in the last decade has outpaced new product development over the past century (Fortin and Uncles, 2011).

More informed customers with higher expectations are evident in the financial services sector, however the increasing complexity of product offerings poses challenges for financial service organizations (Estelami, 2009) as well as societal impacts of the new products (Warren, 2008; Richards, 2009). For example, in recent years, innovative products like the mortgage backed securities, exchange traded funds, and derivatives are now commonplace financial instruments available to the mass market. As well, technology as a key component of infrastructure continues to shape the financial services industry (Jones and Critchfield, 2005). The spread of the internet and internet banking poses new challenges for the financial services industry to innovate in a manner that allows their customers to adopt the innovation, which can be particularly challenging in emerging markets (Ozdemir and Trott, 2009). These advancements also provide opportunity to enhance service to existing markets, and reach entirely new markets. Other important financial services topics have been researched such as intellectual property rights (Mention and Bontis, 2013) and open innovation (Schueffel et al., 2015) to name a few. However, as an overview, the categories represented in Figure 2 are relevant in today's financial services environment. As highlighted, the contextual factors not only impact an organization's current innovation measure, but also the choices an organization will make to reach a desired innovation state. 


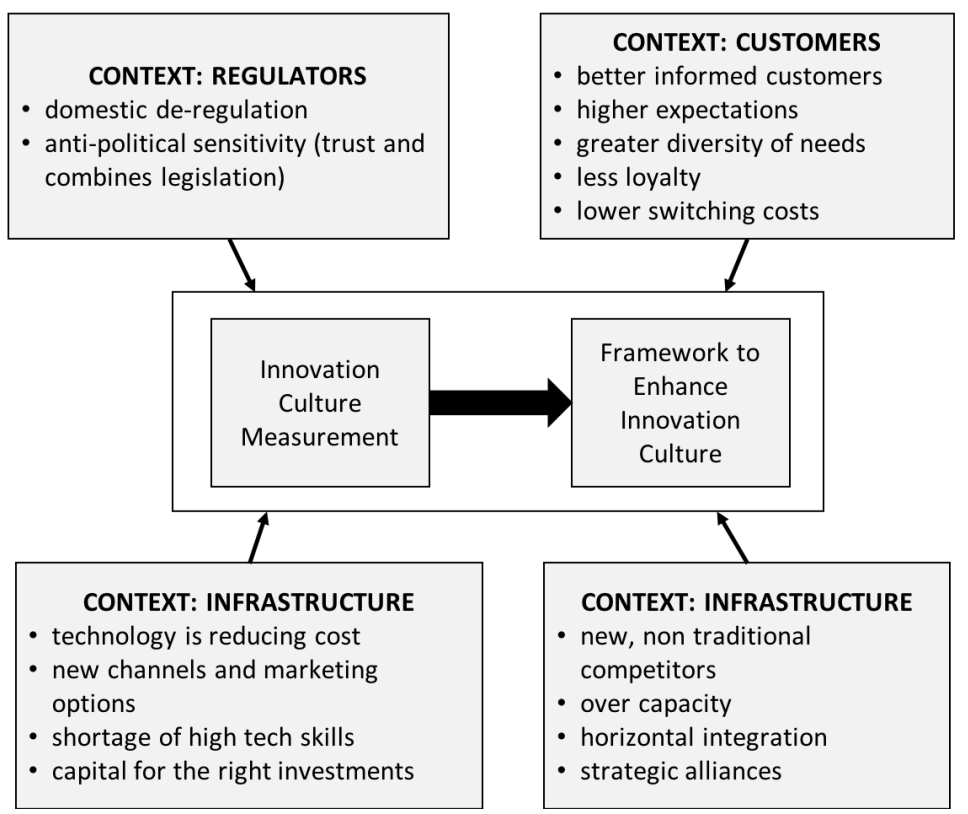

Fig. 2. Financial Services Industry Context (adapted from Dobni, 2006)

\section{Research Methods}

The research approach involved a case study of a financial services organization. Over a four-year period two separate innovation culture assessments were performed using the Dobni model. The organization's innovation efforts were documented as they utilized the assessment as a framework for implementing their innovation agenda. Given the primary researcher's involvement with the organization in assessing the innovation culture, an action research approach (Lewin, 1946, Coughlan and Coughlan, 2002) was adopted. In a traditional case study methodology, the researcher investigates the phenomenon while trying to limit bias in the research (Yin, 2009). In action research, the researcher works collaboratively (Alder et al., 2003) and is more involved in solving and understanding a problem (Patton, 2002). In this case, the problem of investigation was assessing innovation culture and using the assessment outcomes to implement an innovation agenda. The active approach was primarily contained to the innovation culture assessment, in which several meetings with the senior management team of the organization were held to explain and interpret the results.

The choice of case study subject is an important aspect of qualitative research (Yin, 2009). To align the study with our research intent, the subject needed to be an organization that was consciously deciding to embark on becoming more innovative. Additionally, because the research interest was understanding whether the (Dobni 2008) measurement tool could be used as an implementation framework, the subject organization needed to allow the researchers to survey the company employees multiple times, as well as follow the innovation activities of the company. Ideally, the subject company needed a contextual environment that promoted the need for innovation (e.g. highly competitive or changing industry dynamics). This proved challenging to 
actively solicit such candidates. FinanCo approached the lead author after attending presentations and reading publications related to the (Dobni 2008) model. Discussions followed that led to an initial survey instrument measuring the innovation score at FinanCo. The research subject was interested in being able to contribute to scholarly inquiry by allowing further investigation with the forethought of a manuscript that documented their journey. This presented a unique opportunity to perform action research with a research subject that met the needs of the research intent. (Kaplan 1998) espouses the importance of action research to develop new management practices. In many respects the earlier activity based costing and balanced scorecard work of Kaplan with Analog Devices (Kaplan, 1990) followed a similar evolution of research method to the FinanCo project, although other researchers have used action research in the field of innovation (McAdam et al., 2007). Using a single case study allows the researchers to illustrate a conceptual contribution (Siggelkow, 2007) by illustrating how the measurement model can be used as an implementation framework.

From a methodology perspective, the process that followed was a "plan - implement - evaluate" approach (Stringer, 2014). Following the Stringer (2014, p. 9) approach, a series of interactions occurred in a "look-think-act" manner. For example, the researcher would "look" at the survey results, "think" about its meaning in the context of FinanCo s, then "act" through a series of advisory sessions with FinanCo managers. The sessions were both formal in written context or informal discussions. Similarly, when FinanCo was developing implementation actions, feedback was provided from the researcher to FinanCo. Feedback was not in the format of "do this or do that" but more related to interpretation of the survey results and what FinanCo's planned action items could potentially mean in the context of the survey results. These discussions and interactions occurred with the C-suite of FinanCo (president, and VP's of finance, marketing and operations) through a series of meetings, phone calls and workshops. The most extensive interaction occurred between the researcher and the Vice President of Marketing (named Marketsolutions), whom was the chief sponsor. The discussions and interactions with the C-suite led to a series of execution decisions that cascaded into plans and projects throughout the organizations. All functions of the organization were impacted - human resources, finance, operations, marketing and information technology. Thus, began the action research loop of plan - implement - evaluate. The interactions and discussions with the C-suite lead to the initial plans of innovation road-mapping, which were then implemented by a broader team of managers. Checkpoint meetings were held with the C-suite periodically, on average every three to four months, to evaluate progress and adjust plans.

To assess how the research subject used the assessment as an innovation framework the approach was more consistent with traditional case study techniques. A series of semi-structured interviews were performed with senior management to collect information that formed the basis of the research findings. Interview notes were scribed and feedback was obtained to promote internal validity and reduce interpretation gaps of the findings (McKinnon, 1988). Additional information and documentation was obtained from the organization to triangulate the interview findings (Ryan et. al, 2002; Silverman 2001). For example, the organization performed a number of strategy discussions during the implementation period that resulted in action plans and progress reports. These documents were useful in understanding the implementation choices that ultimately evolved. In summary a research protocol of qualitative research using (Yin 2009) and (Nachimias \& Nachimias 1987) was used as guidelines, but the bias of action research is 
recognized a limitation of the study.

\subsection{Choice of Innovation Measurement Model}

Figure 1 Expanding on the scope of inquiry outlined in Figure 1, the model used to measure innovation culture for this research was predicated on a widely tested multi-factor approach that displayed high levels of validity and reliability (Dobni, 2008). The factor analysis and final factor solution supports the model of innovation outlined in Figure 3. This model identifies and measures twelve drivers of innovation and is consistent with the literature on innovation determinants (Crossan and Apaydin, 2010). Through factor analysis and repeated testing of the constructs through multiple studies, the original 117 constructs from the 2008 Dobni model were reduced to 58 (Table 1) that were organized around the twelve drivers.

The four innovation dimensions (leadership, resources, knowledge management and process) conceptualize the innovation implementation framework. For example, the importance of knowledge management to innovation (Esterhuizen et. al, 2012; Ruggles, 1998; Darroch, 2005) is represented as an innovation dimension for implementation and further refined in the model through the drivers: "Knowledge Generation", "Knowledge Transfer" and "Knowledge Decision Making." In this regard, the innovation culture assessment model not only analyzes the capabilities of the organization towards knowledge management but further informs the organization as to what aspects of knowledge management are strong (or weak) for implementation considerations.

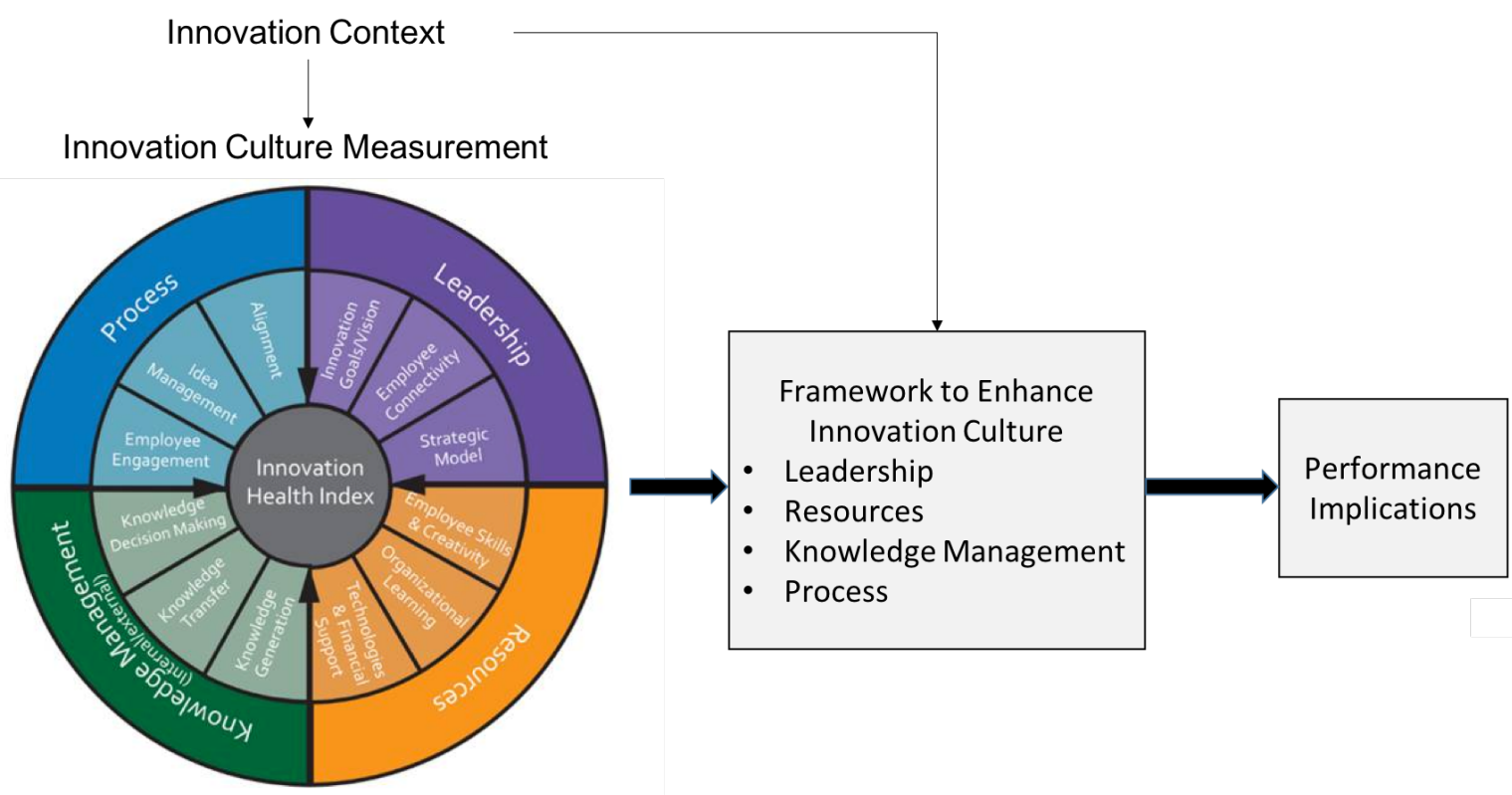

Actual Innovation State

Desired Innovation State

Fig. 3. Innovation Culture Measurement Model building on the Innovation Health Index (Dobni 2018)

Each of the 12 drivers are comprised of a series of constructs developed to quantitatively measure culture supporting the driver. A seven-point Likert scale was used to measure each of the con- 
structs, and then the score was converted to a percentage scale (out of 100). The driver scores are the average of the construct scores within each driver. The dimension scores (i.e. leadership, resources) are an average of the driver scores, and the overall score - the 'Innovation Health Index' - is an average of the 4 dimensions. Given the holistic nature of the model, they are considered equally important, meaning none of the drivers are weighted more or less. Each of the 12 drivers are briefly defined in Table 1 below. Although these drivers have been reported in a previous publication (Dobni and Klassen, 2015) given the importance of this knowledge to understanding the context in support of an implementation framework, we have made the decision to re-introduce them herein.

Table 1. Innovation Drivers (adapted from Dobni and Klassen, 2015)

\begin{tabular}{ll}
\hline IMPLEMENTATION FRAMEWORK DIMENSION: LEADERSHIP \\
\hline Innovation Driver & Explanation \\
\hline $\begin{array}{l}\text { Innovation Goals/Vision } \\
\text { (4 constructs) }\end{array}$ & $\begin{array}{l}\text { The degree to which the organization has formally established - within } \\
\text { their business model - vision and values to develop and sustain inno- } \\
\text { vation. This is communicated through vision, goals, and objectives } \\
\text { that are operationalized through the business model and business pro- } \\
\text { cesses, and strongly adopted by the senior leadership team. }\end{array}$ \\
\hline $\begin{array}{l}\text { Employee Connectivity } \\
(4 \text { constructs })\end{array}$ & $\begin{array}{l}\text { This involves how employees think of themselves vis-a-vis their col- } \\
\text { leagues. For example, do they feel that they can contribute? Do they } \\
\text { feel valued and equitably treated? Do they trust and respect man- } \\
\text { agement? Do they resonate with what the organization is doing, and } \\
\text { are they working together to achieve the vision? }\end{array}$ \\
\hline $\begin{array}{l}\text { Strategic Model } \\
(7 \text { constructs) }\end{array}$ & $\begin{array}{l}\text { Infrastructure for the purposes of innovation involves the business } \\
\text { model employed to support the strategy process and innovation over- } \\
\text { all. }\end{array}$ \\
\hline
\end{tabular}

\section{IMPLEMENTATION FRAMEWORK DIMENSION: RESOURCES}

\begin{tabular}{|c|c|}
\hline $\begin{array}{l}\text { Employee Skills and Creativ- } \\
\text { ity ( } 5 \text { constructs) }\end{array}$ & $\begin{array}{l}\text { The extent to which employees have the skills to be innovative. This } \\
\text { includes levels of personal creativity and the surrounding environment } \\
\text { (time and space) to allow their skills and creativity to be utilized. }\end{array}$ \\
\hline $\begin{array}{l}\text { Organizational Learning } \\
\text { (4 constructs) }\end{array}$ & $\begin{array}{l}\text { Properly tooling employees involves committed education and train- } \\
\text { ing programs that focus on developing processes that facilitate the } \\
\text { learning of new behaviors, and then post training reinforcement. }\end{array}$ \\
\hline $\begin{array}{l}\text { Technical and Financial Sup- } \\
\text { port }(3 \text { constructs })\end{array}$ & $\begin{array}{l}\text { The extent to which the organization provides resources (financial, } \\
\text { time, people, other) to support innovation initiatives. }\end{array}$ \\
\hline \multicolumn{2}{|c|}{ IMPLEMENTATION FRAMEWORK DIMENSION: KNOWLEDGE MANAGEMENT } \\
\hline $\begin{array}{l}\text { Knowledge Generation } \\
\text { ( } 5 \text { constructs) }\end{array}$ & $\begin{array}{l}\text { The environment to support knowledge generation by employees from } \\
\text { all stakeholders of the company including industry and organizational } \\
\text { value chain knowledge. }\end{array}$ \\
\hline
\end{tabular}


Knowledge Dissemination (5 constructs)

Knowledge Decision Making (6 constructs)
The environment to support the dissemination of knowledge to the right people on a timely basis.

The ability of employees, based on knowledge generation and dissemination, to understand the dynamics of their business environment in efforts to define value-added projects and initiatives. These advantages are identified by observing and understanding the industry, competitors and stakeholders, emerging technology, channels, knowledge flows, and future cluster development.

\section{IMPLEMENTATION FRAMEWORK DIMENSION: PROCESS}

\begin{tabular}{ll}
\hline $\begin{array}{l}\text { Employee Empowerment } \\
\text { (5 constructs) }\end{array}$ & $\begin{array}{l}\text { This involves the psychological empowerment of employees and their } \\
\text { perceived ability/confidence to undertake autonomous actions that } \\
\text { contribute to value creation. }\end{array}$ \\
\hline $\begin{array}{l}\text { Idea Management } \\
(4 \text { constructs) }\end{array}$ & $\begin{array}{l}\text { This involves the level or degree to which employees can pursue what } \\
\text { appear to be opportunities or initiatives with less certainty than they } \\
\text { are traditionally comfortable with or for which policies allow for (i.e. } \\
\text { entrepreneurial activity). }\end{array}$ \\
\hline $\begin{array}{l}\text { Alignment } \\
(6 \text { constructs) }\end{array}$ & $\begin{array}{l}\text { This is a measure of alignment to support desired innovation-related } \\
\text { behaviors. For example, the performance management and manage- } \\
\text { ment control systems, and the alignment of innovation strategy with } \\
\text { the organization's strategy. }\end{array}$ \\
\hline
\end{tabular}

\section{Analysis and Results}

The case study that follows presents FinanCo, an organization within the financial services industry that initially scored low on the innovation culture assessment. As the case study will detail, FinanCo, due to systematic deregulation of a highly competitive and regulated business environment, needed to innovate or face extreme negative performance consequences. Over the period of 4 years, through systematic management of an innovation agenda, FinanCo increased their aggregate score by $17 \%$ (from $61 \%$ to $78 \%$ ).

Today FinanCo is a successful organization that has re-invented itself through its pursuit of, and focus on innovation. The case study details their journey including the implementation activities that FinanCo executed to improve their innovation culture. Senior management used the innovation assessment metric to guide the choice and timing of implementation activities with the basic philosophy that if FinanCo became more innovative and strategic, financial performance would improve and the organization would prosper.

\subsection{FinanCo Background}

FinanCo is a financial organization that can be described as a services portal for downstream financial institutions. At the time, FinanCo was owned by over 40 financial institutions in Canada, and they provided all types of services to its member organizations, ranging from a banking system platform, to products and services for clients, to governance and compliance 
services for the system. Before the innovation program, the primary mandate of FinanCo was to offer deposit, loan, and compliance services for the member institutions.

The financial institutions in Canada are structured as typical banks, lending money to, and receiving deposits from individuals and businesses. As indicated, FinanCo provided other services to member institutions such as marketing, human resources and strategic advice, and marketable services. Up and until 2000, their basic deposit/loan business model served them well. In the 2000's the environment began to change. Legislation was passed that supported deregulation. This resulted in increased competition in the financial industry as "non-traditional" banks and the internet banking business models entered the industry, and products and services portfolios expanded into investments, insurance services, and financial planning. Margins began to decrease for financial institutions and in response, many smaller financial institutions began merging to leverage economies of scale, as well as to enhance their lending capability and product offerings. As the mergers continued, two fundamental impacts affected FinanCo. As the merged financial institutions grew in size and scope, some of these larger financial institutions could perform the traditional services that FinanCo was providing, essentially creating competition from within.

Secondly, financial institutions were demanding new services to address competency gaps and create new value for competitive purposes. In some cases, FinanCo may have offered the services (e.g. basic marketing consulting advice or new investment products), but FinanCo was not able to deal with the demand or complexity of the products and services demanded, nor did they have the volume to provide services at competitive rates. The value proposition of FinanCo was quickly eroding, as were profit margins, and member institutions were defecting to more cost-effective and value-added options provided by competitors. FinanCo management decided to use innovation to re-invent their organization in efforts to enhance value for their clients.

\subsection{What Was Planned?}

FinanCo officers discussed options aimed at renewing their market presence and value proposition. They committed to becoming more innovative, which represented a fundamental beginning. The first step taken by FinanCo was to measure their innovation health index (IHI) in efforts to establish a benchmark, and to utilize the index scores across the drivers to develop an innovation implementation plan. Figure 4 describes the results of the initial innovation culture survey. 


\section{FinanCo Year 1 Innovation Health Index - 61\%}

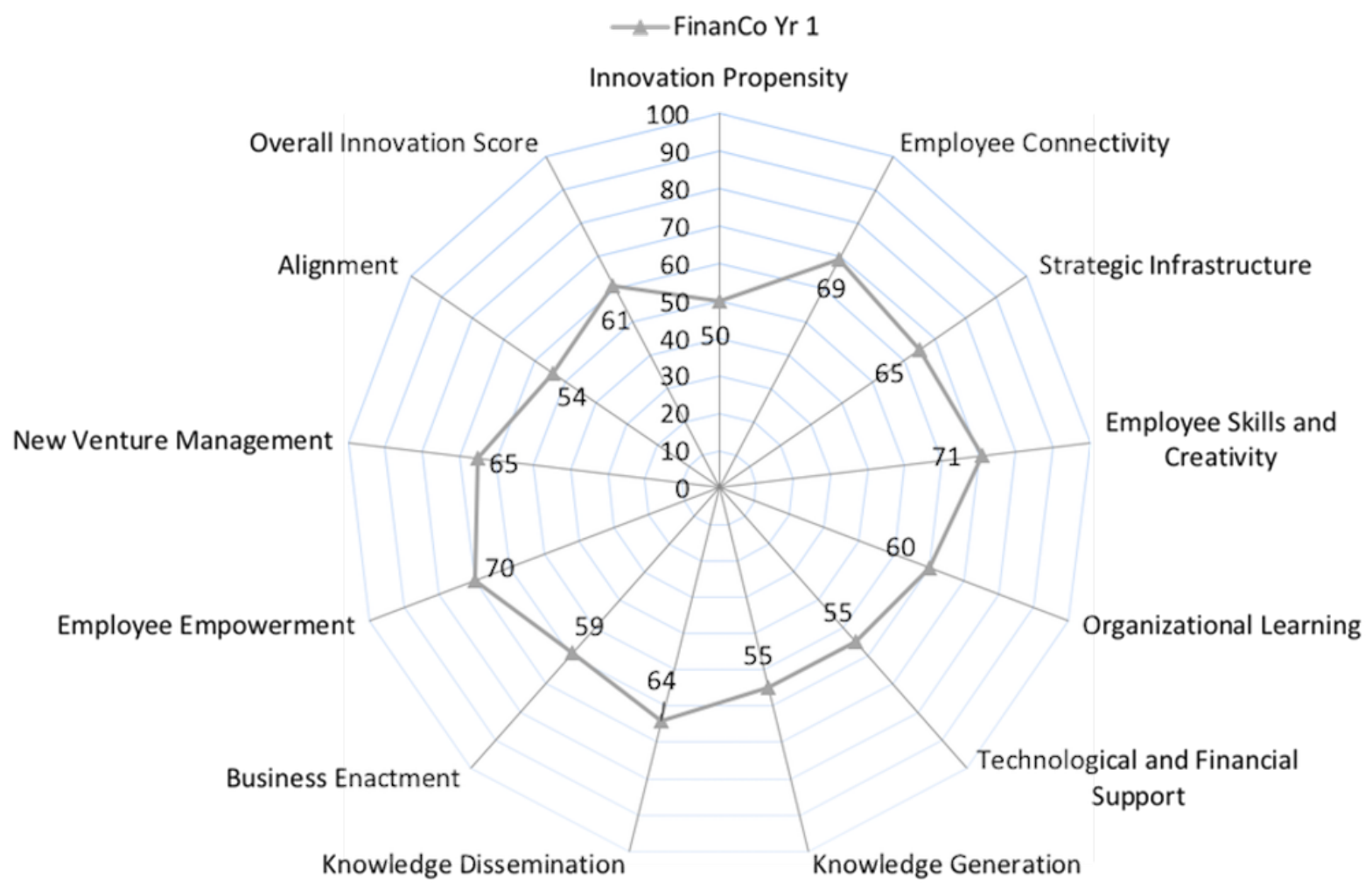

Fig. 4. FinanCo's Initial Innovation Benchmark Score

Initial Conclusions with respect to FinanCo's Innovation. The initial innovation culture score was comparatively low suggesting that FinanCo was not currently innovative. There were issues across-the-board with most of the drivers of innovation, and in particular with their innovation goals and vision (50\%), technological and financial support (at 55\%), knowledge generation (55\%), knowledge decision making (59\%), and alignment (at 54\%). Through analyzing the individual driver scores and in discussions with management, a number of additional contextual insights were derived. It should be noted that the management discussions were an integral part of the survey analysis given that organizational context plays an important role in innovation. Six conclusions regarding FinanCo's innovation culture were provided:

1. Innovation at FinanCo was incremental and random: The low overall score of (Innovation Health Index of $61 \%$ ) suggested that any innovation occurring at FinanCo at that time was small in scale or incremental. Further, innovation was predominantly a result of a random event as opposed to being systematically managed and encouraged by FinanCo. Part in parcel of this was a lack of governance for innovation. Governance for innovation involves oversight of systems and processes to support innovation. At best, it was largely underdeveloped or non-existent. 
2. A lack of innovation strategy: Although FinanCo had a mission, vision and strategy, there was an absence of an intent to be innovative throughout the strategic planning process, nor what they had hoped to achieve through innovation over time. In addition, there was no mechanism in place to communicate the strategic importance of innovation to all employees.

3. Lack of resources to support innovation: Although the technology and financial resource driver scored low (55\%), construct analysis suggested that this issue was more related to inadequate time allowed for innovation and inadequacies in the current technology platform than it was to fund supporting innovation initiatives. Specifically, resources were not formally directed toward innovation initiatives at FinanCo.

4. Employees at FinanCo were creative: This was the "tag line" discussed by management as it related to the creativity and empowerment levels of employees. The score of $71 \%$ suggested that employee creativity were not barriers to innovation at FinanCo. This driver scored amongst the highest of the twelve measured. Alternatively, the leadership for innovation and organizational design, and execution frameworks were impeding innovation implementation, which explained the significant gaps in this area.

5. Creating knowledge did not convert into better decisions respecting innovation: There was a significant difference between FinanCo's ability to generate knowledge and FinanCo's ability to disseminate knowledge, and subsequently use that knowledge to make value-added decisions. Specifically, the scores in the dimension of knowledge management (average of $59 \%$ ) highlighted that fact that the organization was unable to transform knowledge into innovation projects and initiatives.

6. Performance measurement and management did not support innovation: The assessment revealed that there was weak process architecture to cascade innovation goals and strategic information throughout FinanCo. Management control and performance management systems supporting innovation were either lacking or non-existent, and compensatory and incentive structures were misaligned. This dimension scored an average of $54 \%$.

\subsection{What was Acted Upon}

After the initial assessment, FinanCo's senior management group developed a four-year plan to implement change. The following section*s outline the implementation activities FinanCo executed. Although there were changes to the plans throughout the four years, the case study describes the major activities that were pursued.

Figure 5 provides a roadmap of how FinanCo implemented innovation change over a four-year period. The roadmap was developed through the researcher's interpretation of the innovation activities. Although the roadmap evolved over the four-year period, Figure 5 represents the general thrust and timing of the implementation activities in respect to the four dimensions of innovation measured. 


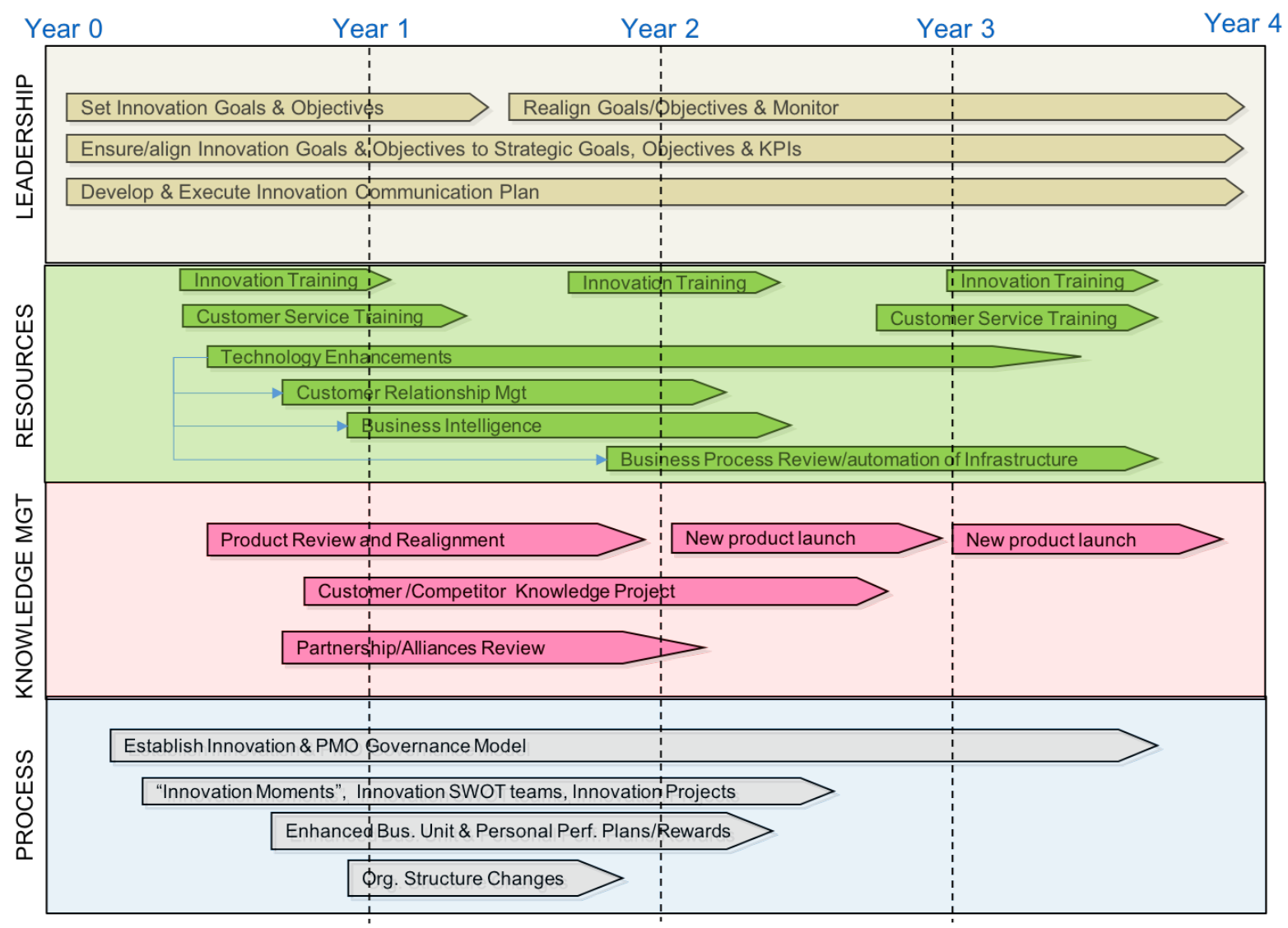

Fig. 5. FinanCo Innovation Implementation Roadmap

The roadmap not only answered the question, "what activities needed to be implemented" but also "the timing of implementation activities." The general principle used in development of the roadmap focused on activities that could be executed quickly and efficiently, and ones that would have maximum impact on the innovation culture for the lowest cost in terms of time and resources. It was thought that 'quick wins' would anchor the innovation culture going forward. In addition, given the low overall score, FinanCo decided that innovation needed to be emphasized across all dimensions of the model. The outcomes of these principles, from a roadmap perspective, explains why FinanCo focused on "leadership" first, followed by activities in the other dimensions. To support the suite of implementation activities, FinanCo was disciplined in using project management techniques to support the implementation effort. The implementation activities for each innovation perspective (leadership, resources, knowledge management and process) are explained below.

General Approaches for Leadership. The foundation of an innovation platform is to launch organizational intent and readiness, and then communicate a commitment to becoming innovative. FinanCo accomplished this by establishing clear innovation goals that both complemented and challenged their current strategy. FinanCo's current strategic process was best described as planned and deliberate. Annually, FinanCo reviewed the strategic goals and amended them as required. By establishing innovation goals, the strategic plan and process became emergent and 
fluid. FinanCo was committed to letting the innovation process drive strategic outcomes. The old strategic plan - which utilized a balanced scorecard approach, had basic strategic objectives of profitability and efficiency measured through key financial performance measures. Examples of the innovation goals and objectives were as follows:

- Having a discernable increase in the innovation culture; measured through the innovation health index;

- Enhancing quality and customer service; measured through surveys and process metrics;

- Improving employee engagement and innovativeness; measured through engagement surveys, training metrics and competency analysis;

- Increasing the product portfolio to be more customer oriented; measured through new products launched and key performance indicators to measure success; and,

- Improving the business processes to obtain better information, improve customer service and becoming more efficient; measured by project management metrics of strategic projects.

Almost immediately after establishing the innovation implementation activities, a communications plan was put in motion. Senior management was aggressive in communicating the goals and commitment to innovation. Company-wide communications, internal meetings, online messaging, and visual media were used to raise awareness of the innovation goals and commitment. The basic message to employees was not only to communicate the innovation goals, but also to emphasize that the employees were the people who would be responsible and empowered to achieve the innovation goals. The result was an increase in innovation goals/vision and connectivity drivers as employees began to understand that the organization was committed to innovation and that collectively all employees would participate in realizing innovation goals. Subtly, the strategic model driver was also improving as the strategic thrust changed from a planned strategic outcome to more of an emergent process as employees realized that new product offerings and adapting their business model was critical to success.

General Approaches for Resources. Once the initial focus on context and execution were enacted, FinanCo addressed the resources and orientation dimensions. The drivers that improve innovation on the resources dimension are related to employee skills and creativity, organizational learning and the technical/financial support. Based on the innovation goals and execution activities, it was apparent to FinanCo that skill gaps were present in customer service and general innovation knowledge. There were also major infrastructure process and technology gaps related to customer information, business intelligence and general operational processes that were inefficient. Investments were made in customer service and innovation training and existing training programs were altered to ensure the customer aspect was continually highlighted. Larger information system and process improvement projects were launched to improve customer relationships and business intelligence, including the implementation of a new banking system. These projects were essential to tool FinanCo with the information to launch and monitor customer relevant products and services. They were also essential to provide information to execute other projects recommended by the innovation team, and to provide information to monitor and 
realign the innovation goals in future years. In this respect, the projects improved the innovation culture in the context and execution dimensions.

One of the challenges of major process improvement or technology implementation is change management. The activities FinanCo undertook related to changing employee orientation meant that in general, employees had to become more adaptive to change, and understood the imperative to change. Improving the processes while adopting the new technologies was also easier as employees' innovation propensity and connectivity had begun to improve by the time the technology and process improvement initiatives started.

General Approaches for Knowledge Management. An integral dimension for innovation is knowledge management, where the key drivers of innovation are generating and disseminating knowledge related to the industry, competitors and clients and being able make value added decisions in respect to that knowledge. The technology and process initiatives previously discussed (particularly customer relationship management and business intelligence) provided the basis for knowledge generation. However, two gaps remained, inclusion of information from partners and alliances (open innovation concepts) and developing a process to disseminate knowledge. These two gaps were ultimately closed by initiating a knowledge management project. Communication and reporting processes were developed that included collecting information from external partners and alliances. Through this process, FinanCo ultimately launched new or improved products and services that created better value. New products were launched because of the collective knowledge generated and disseminated. Not only did FinanCo begin to develop more competitive products and services, but also had the right people, processes and technologies in place to support the markedly improved portfolio.

General Approaches for Process. Finally, FinanCo needed to improve its processes directed at the ability to execute initiatives. Prior to deregulation, execution was not as important because the business model and related activities performed by employees were generally stable from year to year. Moving forward, the amount of change required to achieve and sustain innovation goals would require employees to not only embrace change, but also deliver on performing new tasks. From an innovation perspective, execution is achieved through increased employee empowerment and creating a culture where employees embrace new ideas and risk, and have a defined process to implement new ideas. To ensure ideas and empowerment are focused in the right direction, alignment of processes that support innovation is paramount.

To improve execution FinanCo created an innovation team armed with a mandate and budget to achieve the innovation goals at FinanCo. The team was comprised of a cross section* of employees from the organization, ranging from senior managers through to operational employees. Prior to deregulation, senior managers were responsible for achieving goals, the decision-making structure, and the implementation environment. To a certain extent, this did not change. However, the innovation team gave management a new tool to assist in execution and created a culture where employees were more active in decision making and execution, as well as embedding the innovation culture.

The innovation team has a wide-open agenda as it related to 'getting things going'. For example, they developed programs such as "innovation moments," that ensured all working groups in FinanCo were allowed time to "blue sky" ideas to achieve the innovation goals. For specific innovation projects, teams were assembled - similar to a SWAT team, which was given a man- 
date to solve problems or enact opportunities. The innovation team was also responsible for providing direction to innovation projects. In some cases, projects were deemed, "quick wins" and executed immediately and without sanction by the SWAT teams, whereas larger projects such as information system improvements were labeled as a key innovation projects subject to a charter. The innovation team was given the resources to advance these larger projects.

One of the traditional adjustments FinanCo made to their implementation environment was changes to their organization structure. In general, the organizational structure changed to become more customer-centric and aligned with functional areas grouped around product and service offerings as opposed to core functional areas such as finance and human resources which became support entities within the structure. Similarly, performance management systems changed to accommodate innovation goals and reward employees for ideas, or successful implementation of innovative projects.

\subsection{What was the Result?}

Did the innovation implementation activities work? To determine this, an additional assessment of their innovation health index was completed using the same assessment metric, at the beginning of year 4 of the initiative. Over this period, FinanCo improved their IHI score by $17 \%$ overall; from $61 \%$ initially, to $78 \%$ at the end of the implementation period. Figure 6 below illustrates the changes in IHI scores over the period of study.

\section{FinanCo Year 1 vs. Year 4 Innovation Health Index}

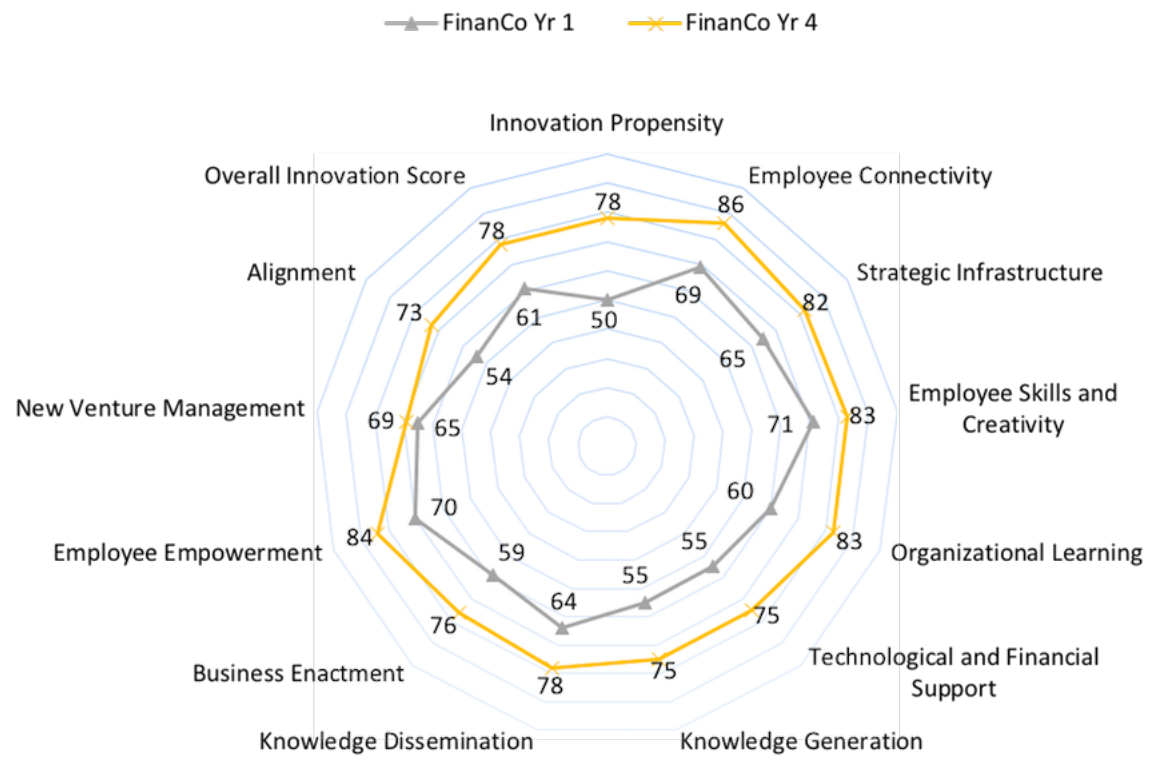

Fig. 6. FinanCo's Year 1 vs. Year 4 Innovation Health Index Score 
Figure 6 outlines some interesting changes over a four-year period. For example, scores across all 12 drivers of innovation increased, with the largest increase coming from the "innovation goals/vision driver." Also noted over time was a more balanced approach to innovation, as the team focused on drivers that needed more emphasis than others (as identified by an interim assessment two years out (measures which indicated variable progress). This customized approach lead to a more efficacious and targeted use of time and resources in support of innovation.

Areas that proved to more difficult to move forward were drivers grouped in the "Knowledge Management" dimension and the "Process" dimension. This was not surprising given that these cultural dimensions in organizations are often more deeply rooted and difficult to affect over a shorter time horizon. The executive team also noted that innovation became more systematic and planned, and that employees better understood how their actions and behaviors correlated with innovation. This was not the case initially where it was evident that innovation efforts at FinanCo were random and sporadic.

Lastly, management also reported that the strategy process itself become more articulate and smoother - from strategy formulation through to strategy implementation. This theme of better execution of existing strategy was not a surprise and is consistent with findings related to the relationship between innovation culture and positioning and performance outcomes. In addition, there were two other proxies of success. At the end of the 5-year period, FinanCo reported their highest net income in history, and the organization was awarded the "top 100 workplaces in Canada" by Canada's premiere news outlet, the Globe and Mail. The case study suggests that FinanCo was successful in advancing their innovation culture through a multi-pronged implementation effort. Consistent with our innovation implementation model (Figure 1), the case study suggests that enhanced innovation culture was a contributing factor to superior performance at FinanCo.

\section{Discussion of Findings}

The importance of innovation is generally well accepted by managers, practitioners and academics. However, implementing an innovation agenda is difficult and although many organizations have good intentions, this may not be enough. The contribution of this research was to understand if the innovation cultural assessment model could be utilized as a framework to assist financial services organizations in making decisions with respect to implementing their innovation activities given the context specific to their organization. The FinanCo case study illustrates that the model is useful to assess the current state, and guide decisions on implementing change in support of an innovation culture. This informs academic innovation research overall and within the financial services industry as well as managers concerned with implementing activities to implement innovation change. The findings in this case study illustrate that the (Dobni 2008) model, when used as an innovation culture assessment measure then an innovation implementation framework, is informative to academics and managers. 


\subsection{Academic Considerations}

Our study contributes to the growing research that investigates the linkage between innovation culture, strategy and performance (Naranjo Valencia et al. 2010, Aas and Pedersen, 2011; Christensen and Raynor, 2003; Govindarajan and Trimble, 2005). The case study provides additional support for the notion of complex and multi-dimensional aspects of both innovation and culture. The primary value of this research to academic literature is the framing of the measurement tool to an implementation framework. Our view is this provides a more holistic approach to researching innovation and therefore allows previous research to connect though the innovation implementation framework. For example, our research echoed (Darroch 2005) research on knowledge management capabilities and innovation performance by illustrating the FinanCo's knowledge management activities. However, our case study also shows that the knowledge management activities are bound to a portfolio of activities in knowledge management as well as activities in leadership, process and resources. Similarly, our case study supported the findings of (Jimenez-Jimenez \& Sanz-Valle 2011) of organizational learning positively impacting innovation and performance. In the case study, innovation training was a key aspect of advancing the innovation agenda. However, the implementation framework, through the case study, also highlighted relationships with organizational learning and the resources committed to innovation, leadership and a process to govern innovative ideas. Previous research was also supported in leadership (Mumford and Licuanan, 2004; Crossland and Hambrick, 2007, organizational structure (Damanpour, 1991; West et al., 1998, and learning and knowledge management tools (Crossan et al., 1999; Alexy et al., 2013). However, our case study found additional context and innovation implementation activities that were informatively explained though the measurement and implementation framework. The framework can be useful to academics to ensure context and multiple aspects of innovation are considered. The findings are similar to the contextual innovation views (Ortt \& van der Duin, 2008; Van der Duin et al., 2014) and support a contingency theory (Chenhall, 2003; Burns and Stalker, 1961; Woodward,1965; Lawrence and Lorsch, 1967) orientation.

We found notable evidence that innovation was integral to the aspects of the financial services, supporting our literature review and case study subject choice. Previous financial services research findings in regulation issues (Bos et al., 2013; Nejad \& Estalami, 2012) and product development (Estelami, 2009; Jones and Critchfield, 2005) were very apparent in the case study analysis. However, our case study illustrated that an implementation framework addresses issues raised in previous financial services innovation literature. For example, the case study illustrates how the implementation framework was used to create an action plan that addressed many of the innovation barriers raised by (Vermeulen 2004, Vermeulen 2005). The concept of Fintech as described by (Schueffel 2016) seemed to be an appropriate contextual description for FinanCo, and there is little reason to doubt this will not continue, further highlighting the need for innovation implementation frameworks. Newer technologies such as blockchain, internet of things and artificial intelligence, although not formally analyzed in this case study, will undoubtedly shape innovation discussions and plans in the financial services sector. 


\subsection{Management Considerations}

Over the course of working with others and with FinanCo dating back nearly 15 years, we have gained many valuable insights that we believe have a common theme as it relates to advancing innovation in financial services organizations specifically and other organizations in general. Through other research (Dobni and Klassen, 2015), our content analysis discovered successful traits and themes as identified by senior executives. These were brought to light in the FinanCo case, and we have made the linkages below were possible:

1. The organization must be committed to institutionalizing innovation as a core strategy rather than using the term ubiquitously. The presence of a clear 'innovation strategy' will signal the importance of innovation to the organization. FinanCo's greatest gains over the 4-year period was resident in the driver of 'innovation goals/vision.' This was not a surprise as they expended a great deal of time and effort to establish this foundation.

2. Innovation culture should be measured so that an organization can establish a baseline of their current innovation state and for the purposes to measure and monitor improvement over time. The initial assessment at FinanCo helped to establish a targeted roadmap to support innovation culture change.

3. It will take years, not months, to embed sustainable change in the organization's innovation culture. Therefore, organizations need to have a medium to long-term agenda, as well as be persistent in the pursuit of advanced innovation cultures. For FinanCo, this process unfolded over a four-year period, and continues today as innovation became embedded in their culture.

4. Innovation can appear complex for organizations, so it is important to develop a simple governance approach to innovation that allows for the progression of ideas from initial stimulus through to implementation. Early and inexpensive wins are essential in reinforcing the innovation program. The establishment and formal recognition of the 'innovation team' at FinanCo proved to be a body that provided fuel and sustained momentum. It was also beneficial that a significant number of employees were engaged in innovation activities directly or by supporting others. Noteworthy to this is the fact that all employees at FinanCo were surveyed at all intervals. This proved to be an avenue for employees to provide further input into the process - such as the identification of barriers to innovation, and input into improving the innovation process overall.

5. Resources, time and space need to be dedicated to support innovation agendas. We have encountered situations where innovation is used loosely and programs ran from 'the side of a desk.' These thrusts will ultimately result in false starts and failed initiatives. Dedicated support mechanisms and resources (human and financial) need to exist in efforts to encourage the use of a consistent innovation process. Examples include tools and processes, internal champions, teams or experts, formal training programs, and a targeted innovation fund to name a few. FinanCo set aside employee time and committed an innovation fund specifically dedicated toward innovation. This fund eventually became a formalized budget item. 
6. It is important that a system not only needs to be in place to capture knowledge, but to effectively communicate and disseminate knowledge to the point that information can be used by employees for decision making support as it concerns innovation. FinanCo undertook a communications audit with the objective to clarify and integrate information assets such as databases, policies, procedures, and communication flows with the decisionmaking models.

7. Finally, the support for innovation behaviors of employees must be embedded in the performance management system. At FinanCo, innovation goals became part of the individual employee performance plan. Employees were then formally evaluated and rewarded in respect to achievement of these goals. Management was also cognizant to engage in informal acknowledgements such as recognition and other non-compensatory rewards.

\section{Conclusion}

The role of innovation is becoming increasingly more important in organizations today. Management is beginning to realize that innovation creates long-lasting advantages and produces dramatic shifts in competitive positioning. Successful implementation of innovation activities will lead to an innovative culture. This in turn can provide a competitive advantage and industry leading performance.

Generalization of a single case study to a larger population is difficult and given the uniqueness and context of financial service organizations, we would not suggest that FinanCo's experience could be generalized across an industry. Further research on using the (Dobni 2008) model as an innovation implementation framework in other case study settings across multiple industries would enhance validity. Given the action oriented nature of the research method, the experience of the authors and familiarity with the measurement tool certainly provided added judgement to FinanCo that independent users may not have. Further replication of the study, by researchers and organizations less familiar with the measurement tool and framework would also enhance validity. One of the limitations and an area that needs to be advanced is the relationship between the determinants within the measurement model and implementation framework. One of the most basic questions asked by management is, "What should we do first?" This is not an easy answer, but could be advanced through empirical work on the relationship between the innovation drivers in the (Dobni 2008) model.

What we have learned from this action research case study is that pursuing an innovation culture can be accomplished on a systematic and planned basis. Initially, organizations can benefit the most from are investments in leadership, and initializing discussions around innovation. It is important are not only creative but also empowered. Economic and competitive issues are not treated solely as obstacles, but rather an imperative for innovative change. It is a challenging environment, and the key question becomes one of how C-suite executives should focus their limited time and resources on a handful of key drivers that support innovation. CEO's that get it have already communicated a strong case for change, obtained senior leadership resolve, and have strategically analyzed the innovation activity choices to execute innovation through an integrated approach. 


\section{References}

Aas, T. H. and Pedersen, P. E. (2011). The impact of service innovation on firm-level financial performance. The Service Industries Journal, 31 (13), 2071-2090.

Adler, N., Shani, A.B.R. and Styhre, A. (2003). Collaborative Research in Organizations: Foundations for Learning, Change, and Theoretical Developments. Los Angeles, CA: Sage Publications.

Aghion, P. and Griffith, R. (2005). Competition and Growth: Reconciling Theory and Evidence. Cambridge, MA: MIT Press.

Ahmed, P. (1998). Culture and climate for innovation. European Journal of Innovation Management, 1(1): 30-43.

Akamavi, R.K. (2005). A research agenda for investigation of product innovation in the financial services sector. Journal of Services Marketing, 19(6), 359-378.

Alexy, O., George, G. and Salter, A. (2013). Cui bono? The selective revealing of knowledge and its implications for innovative activity. Academy of Management Review, 38(2), 270-291.

Amit, R. and Schoemaker, P. (1993). Strategic assets and organizational rent. Strategic Management Journal, 14(1), 33-46.

Arner, D. W., Barberis, J., \& Buckley, R. P. (2017). FinTech, RegTech, and the reconceptualization of financial regulation. Northwestern Journal of International Law \&3 Business, 37(3), 371-413.

Audretsch, D. B. (1995). Innovation, growth and survival. International journal of industrial organization, 13(4), 441-457.

Baregheh, A., Rowley, J., \& Sambrook, S. (2009). Towards a multidisciplinary definition of innovation. Management Decision 47(8), 1323-1339.

Bos, J., Kolari, J. and van Lamoen, R. (2013). Competition and innovation: Evidence from financial services. Journal of Banking \& Finance, 37(5): 1590-1601.

Bukowitz, W. (2013). Fidelity Investments: adopting new models of innovation. Strategy \& Leadership, 41(2), 58-63.

Burns, T. and Stalker, G.M. (1961). The Management of Innovation. London, UK: Tavistock Publishing.

Calantone, R.J., Cavusgil, S.T. and Zhao, Y. (2002). Learning orientation, firm innovation capability, and firm performance. Industrial Marketing Management, 31, 515-524.

Cameron, K.S. and Quinn, R.E. (1999). Diagnosing and Changing Organizational Culture. Based on the Competing Values Framework. Reading, MA: Addison-Wesley.

Chatman, J. A. and Jehn, K. A. (1994). Assessing the relationship between industry character- 
istics and organizational culture: How different can you be? Academy of Management Journal, $37(3), 522-554$.

Chenhall, R. H. (2003). Management control systems design within its organizational context: Findings from contingency-based research and directions for the future. Accounting, Organizations and Society, 28(2), 127-168.

Christensen C. M. and Raynor, M. (2003). The Innovator's Solution: Creating and Sustaining Successful Growth. Boston, MA: Harvard Business School Press.

Christensen, C.M. (1997). The Innovator's Dilemma. Boston, Ma: Harvard Business School Press.

Cooper, R. G., Edgett, S. J., and Kleinschmidt, E. J. (1999). New product portfolio management: Practices and performance. The Journal of Product Innovation Management,16(4): 333-351.

Cooper, R.G. (2000). New product performance: what distinguishes the star products. Austrian Journal of Management, 25, 17-45.

Cordero, R., Farris, G.F. and DiTomaso, N. (2013). Weekly, technical and administrative work hours: Relationships to the extent $\mathrm{R}$ and $\mathrm{D}$ professionals innovate and help to manage the innovation process. The Journal of High Technology and Management Research, 24(1), 64-75.

Coughlan, P. and Coghlan, D. (2002). Action research for operations management, International Journal of Operations \&3 Production Management, 22(2), 220-240.

Crossan, M. M., Lane, H. W., and White, R. E. (1999). An organizational learning framework: From intuition to institution. Academy of Management Review, 24(3), 522-537.

Crossan, M.M. and Apaydin, M. (2010). A mullti-dimensional framework of organizational innovation: A systematic review of the literature. Journal of Management Studies, 47(6), 11541191.

Crossland, C. and Hambrick, D. C. (2007). How national systems differ in their constraints on corporate executives: A study of CEO effects in three countries. Strategic Management Journal, 28(8), 767-782.

Damanpour, F. (1991). Organizational innovation: A meta-analysis of effects of determinants and moderators. Academy of Management Journal, 34(3), 555-591.

Darroch, J. (2005). Knowledge management, innovation and firm performance. Journal of Knowledge Management, 9(3), 101-115.

Denison, D. (1990). Corporate Culture and Organizational Effectiveness. New York, NY: Wiley.

Dobni C.B., and Luffman, G., (2003). Determining the Scope and Impact of Market Orientation Profiles on Strategy Implementation and Performance. Strategic Management Journal, 24(6), $577-585$.

Dobni, C.B. (2008). Measuring innovation culture in organizations: The development of a generalized innovation culture construct using exploratory factor analysis. European Journal of Innovation Management, 11(4), 539-559.

Dobni, C.B. (2010). The Relationship between an Innovation Orientation and Competitive 
Strategy. International Journal of Innovation Management, 14(2), 331-357.

Dobni, C.B. (2011). The Relationship between an Innovation Orientation and Organizational Performance. International Journal of Innovation and Learning, 10(3), 226-240.

Dobni, C.B. (2018). InnovationOne. Innovation One Health Index. Accessed 22th February 2018. http://innovationone.io/

Dobni, C.B., (2006). Developing an Innovation Orientation in Financial Services Organizations. Journal of Financial Services Marketing, 11(2), 166-179.

Dobni, C.B., and Klassen, M. (2015). Advancing an Innovation Orientation in Organizations: Insight from North American Business Leaders. Journal of Innovation Management, 3(1), 104121.

Donaldson, L. (2001). The Contingency Theory of Organizations. Thousand-Oaks, CA: Sage Publications.

Drew, S.A., (1995). Accelerating innovation in financial services. Long Range Planning, 28(4), $1-21$.

Drucker, P. (1991). The new productivity challenge. Harvard Business Review, (NovemberDecember),69-79.

Estelami, H. (2009). Cognitive drivers of suboptimal financial decisions: Implications for financial literacy campaigns. Journal of Financial Services Marketing, 13(4), 273-283.

Esterhuizen, D., Schutte, C.S.L. and du Toit, A.S.A. (2012). Knowledge creation processes as critical enablers for innovation. International Journal of Information Management, 32(4), 354-364.

Fortin, D. \& Uncles, M. (2011). The first decade: Emerging issues of the twenty-first century in consumer marketing. The Journal of Consumer Marketing, 28(7), 472-475.

Gallouj, F., \& Savona, M. (2009). Innovation in services: a review of the debate and a research agenda. Journal of evolutionary economics, 19(2), 149-172.

Govindarajan, V. \& Trimble, C. (2005). Organizational DNA for strategic innovation. California Management Review 47(3), 47-76.

Hamel, G. (2002). Leading the Revolution. New York: Plume.

Hamel, G. (2006). The why, what and how of innovation management. Harvard Business Review, (February), 72-84.

Hammer, M. (2004). Deep change: How operational innovation can transform your company. Harvard Business Review, 82(4), 84-96.

Harborne, P. \& Johne, A. (2002). Many leaders make light work in banking innovation projects. Journal of Financial Services Marketing, 6(3), 267-280.

Hartmann, A. (2006). The role of organizational culture in motivating innovative behaviour in construction firms. Construction Innovation 6(3), 159-172.

Hellriegel, D., Slocum, J.W. \& Woodman, R.W. (1998). Organizational Behavior, 8th ed. Cincin- 
nati, OH: South-Western College.

Higgins, J. \& Mcallaster, C. (2002). What innovation? Then use cultural artifacts that support it. Organizational Dynamics, 31(1), 74-84.

Ittner, C.D., Larcker, D.F. \& Randall, T. (2003). Performance implications of strategic performance measurement in financial services firms. Accounting, Organizations and Society, 28(7), 715-741.

Jaruzelski, B., Staack, V., \& Goehle, B. (2014). Proven Paths to Innovation Success: Ten years of research reveal the best RED strategies for the decade ahead. Accessed 17th December, 2014. url: https://www.strategyand.pwc.com/media/file/Proven-Paths-to-Innovation-Success.pdf.

Jassawalla, A.R. \& Sashittal, H.C. (2002). Cultures that support product innovation processes. Academy of Management Executive, 16(3), 42-53.

Jimenez-Jimenez, D. \& Sanz-Valle, R. (2011). Innovation, organizational learning, and performance. Journal of Business Research, 64(4), 408-417.

Johne, A. \& Harborne, P. (2003). One leader is not enough for major new service development: Results of a consumer banking study. The Service Industries Journal, 23(3), 22-39.

Jones, K.D. \& Critchfield, T. (2005). Consolidation in the US banking industry: is the "long, strange trip" about to end? FDIC Banking Review, 17(4), 31-61.

Kaplan, R. (1990). Analog Devices Inc.: The Half-Life System. Harvard Business Review, March.

Kaplan, R. (1998). Innovation Action Research: Creating New Management Theory and Practice. Journal of Management Accounting Research, 10, 89-118.

Kaplan, R. \& Norton, D. (1992). The Balanced Scorecard - Measures That Drive Performance. Harvard Business Review, (January-February), 71-79.

Kline, S. J., \& Rosenberg, N. (2010). An overview of innovation. Studies On Science And The Innovation Process: Selected Works of Nathan Rosenberg, 173-203.

Klomp, L. \& van Leeuwen, G. (2001). Innovation is not a linear process. Research Management, 8(3), 343-364.

Lau, C.M. \& Ngo, H.Y. (2004). The HR system, organizational culture, and product innovation. International Business Review, 13(6), 685-703.

Lawrence, P. \& Lorsch, L. (1967). Organization and Environment. Homewood Ill: Irwin.

Lewin, K. (1946). Action research and minority problems. Journal of Social Issues, 4, 34-46.

Li, T. \& Calantone, R.J. (1998). The impact of market knowledge competence on new product advantage: conceptualization and empirical examination. Journal of Marketing, 62(1), 13-29.

Martins, E.C. \& Terblanche, F. (2003). Building organizational culture that stimulates creativity and innovation. European Journal of Innovation Management, 6(1), 64-74.

McAdam, R., Keogh, W., Reid, R.S. and Mitchell, N. (2007). Implementing innovation management in manufacturing SMEs: a longitudinal study. Journal of Small Business and Enterprise 
Development, 14(3), 385-403.

McKinnon, J. (1988). Reliability and validity in field research: some strategies and tactics. Accounting, Auditing and Accountability, 1(1), 34-54.

McLean, L.D. (2005). Organizational Culture's Influence on Creativity and Innovation: A Review of the Literature and Implications for Human Resource Development. Advances in Developing Human Resources, 7(2), 226-246.

Mention, AL, \& Bontis, N. (2013). Intellectual capital and performance within the banking sector of Luxembourg and Belgium. Journal of Intellectual Capital, 14(2), 286-309.

Mention, AL. (2012). Intellectual capital, innovation and performance: A systematic review of the literature. Business and Economic Research, 2(1).

Mention, AL. \& Asikainen, AL. (2012). Innovation \& productivity: investigating effects of openness in services. International Journal of Innovation Management, 16(03).

Miles, R. \& Snow, C. (1978). Organizational strategy, structure and process. New York: McGrawHill.

Miller, D. \& Friesen, P.H. (1982). Innovation in conservative and entrepreneurial firms: two models of strategic momentum. Strategic Management Journal, 3(4), 1-24.

Miron, E., Erez, M. \& Naveh, E. (2004). Do personal characteristics and cultural values that promote innovation, quality and efficiency compete or complement each other? Journal of Organizational Behaviour, 25(2), 175-199.

Mumford, M. D. \& Licuanan, B. (2004). Leading for innovation: conclusions, issues, and directions'. Leadership Quarterly, 15(2), 705-50.

Mumford, M.D. (2000). Managing creative people: strategies and tactics for innovation. Human Resources Management Review, 10(3), 313-351.

Nachmias, D. \& Nachmias, C. (1987). Research Methods in the Social Sciences. New York, NY: St. Martin's Press.

Nambisan, S. (2013). Industry technical committees, technological distance, and innovation performance. Research Policy, 42(4): 928-940.

Naranjo Valencia, J., Sanz Valle, R. \& Jimenez-Jimenez, D. (2010). Organizational culture as determinant of product innovation. European Journal of Innovation Management, 13(4), 466480 .

Nejad, M. G. \& Estelami, H. (2012). Pricing financial services innovations. Journal of Financial Services Marketing, 17(2), 120-134.

Nekrep, M. (2013). Innovativeness of banks and insurance companies in developing markets: Guidelines for success. Nase Gospodarstvo, 59(3-4), 39-49.

Ortt, J.R. \& Van der Duin, P.A. (2008). The evolution of innovation management towards contextual innovation. European Journal of Innovation Management, 11(4), 522-538.

Ozdemir, S. \& Trott, P. (2009). Exploring the adoption of a service innovation: A study of 
internet banking adopters and non-adopters. Journal of Financial Services Marketing, 13(4), 284-299.

Patton, M. (2002). Qualitative Research and Evaluation Methods. Thousand Oaks, CA: Sage.

Prahalad, C.K. \& Hamel, G. (1990). The core competence of the corporation. Harvard Business Review, 68(3): 79-91.

Richards, J. (2009). Common fallacies in law-related consumer research. Journal of Consumer Affairs, 43(3): 174-180.

Robbins, S.P. (1996). Organizational Behavior: Concepts, Controversies, Applications, 7th ed. Englewood Cliffs, NJ: Prentice-Hall.

Ruggles, R. (1998). The state of the notion: knowledge management in practice. California Management Review, 30(3), 80-89.

Ryan, B., Scapens R. \& Theobald, M. (2002). Research Method and Methodology in Finance and Accounting. London, UK: Thomson.

Schein, E.H. (1984). Coming to a new awareness of organizational culture. Sloan Management Review, Winter, 3-16.

Schneider, L.A., Shaul, M.A.Z., \& Lascelles, C.K. (2016). Regulatory priorities for fintech firms. Journal of Taxation $\&$ Regulation of Financial Institutions, 29(4), 5-14.

Schueffel, P. (2016). Taming the Beast: A Scientific Definition of Fintech. Journal of Innovation Management, 4(4), 32-54.

Schueffel, P., Edmund, P. \& Vadana L. (2015). Open innovation in the financial services sector - a global literature review. Journal of Innovation Management, 3(1), 25.

Senge, P.M. and Carstedt, G. (2001). Innovating out way to the next industrial revolution. Sloan Management Review, 42(2), 24-38.

Siggelkow, N. (2007). Persuasion with case studies, The Academy of Management Journal, 50(1), $20-24$.

Silverman, D. (2001). Interpreting Qualitative Data: Methods for Analysing Talk, Text and Interaction. London, UK: Sage Publications.

Stringer, E. T. (2014). Action research. Thousand Oaks, CA: Sage Publications.

Thompson, J.D. (1967). Organizations in Action. New York: McGraw-Hill.

Thuriaux-Aleman, B., Eager, R., \& Johansson, A. (2013). Getting a Better Return on Your Innovation Investment - Results of the 8th Arthur D. Little Global Innovation Excellence Study. Accessed 17th December, 2014.

url: http://www.adlittle.com/sites/default/files/viewpoints/TIM_2013_Innovex_Report.pdf. Tippling, J. \& Zeffren, E. (1995). Assessing the value of your technology. Research-Technology Management, 38(6): 22-40.

Valencia, N., Raquel, S.V., \& Jimenez-Jimenez, D. (2010). Organizational culture as determinant of product innovation. European Journal of Innovation Management, 13(4), 466-480. 
Van de Ven, A. H. (1986). Central problems in the management of innovation. Management Science, 32(5), 590-607.

Van der Duin, P.A., Ortt, J. R. \& Aarts, W. T. M. (2014). Contextual innovation management using a stage-gate platform: The case of philips shaving and beauty. The Journal of Product Innovation Management, 31(3), 489-500.

Vermeulen, P. (2004). Managing product innovation in financial services firms. European Management Journal, 22(1), 43-50.

Vermeulen, P. (2005). Uncovering barriers to complex incremental product innovation in small and medium-sized financial services firms. Journal of Small Business Management, 43(4), 432452 .

Vermeulen, P., \& Dankbaar, B. (2002). The organisation of product innovation in the financial sector. The Services Industries Journal, 22(3), 77-98.

Wang, C.L. \& Ahmed, P.K. (2004). The development and validation of the organizational innovativeness construct using confirmatory factor analysis. European Journal of Innovation Management, 7(4), 303-313.

Warren, E. (2008). Product safety regulation as a model for financial services regulation. Journal of Consumer Affairs, 42(3), 452-460.

West, M. A., Smith, H., Feng, W. L., \& Lawthom, R. (1998). Research excellence and departmental climate in british universities. Journal of Occupational and Organizational Psychology, $71,261-281$.

West, M.A. \& Farr, J.L. (1990). Innovation at work. In West, M.A., and Farr, J.L. (Eds), Innovation and Creativity at Work: Psychological and Organizational Strategies. Chichester: Wiley, 3-13.

Wong, K.S. (2012). The influence of green product competitiveness on the success of green product innovation: Empirical evidence from the Chinese electrical and electronics industry. European Journal of Innovation Management, 14(4), 468-490.

Woodward, J. (1965). Industrial Organizations: Theory and Practice. London, UK: Oxford University Press.

Yin, R. (2009). Case Study Research: Designs and Methods. Thousand Oaks CA: Sage Publications. 


\section{Biographies}

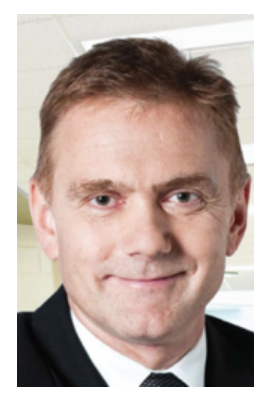

Brooke Dobni. Dr. Brooke Dobni is a Professor of Strategic Management at the Edwards School of Business, University of Saskatchewan. He is the past holder of the PotashCorp Chair for Saskatchewan Enterprise, and a Hanlon Scholar in International Business. Dr. Dobni's research focuses on identifying innovation enhancers, and defining the relationship between strategy, innovation, and organizational performance. Dr. Dobni maintains an active consulting portfolio, helping organizations integrate innovation into their strategic processes.

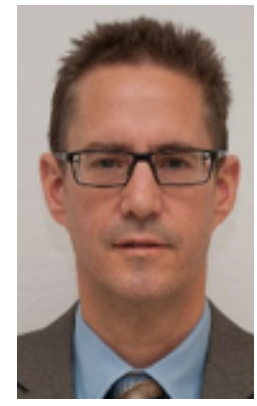

Mark Klassen. Dr. Klassen is an Assistant Professor in the Department of Accounting at the Edwards School of Business in Saskatoon, Canada. He is a CPA and has been recognized as a fellow (FCPA) in the CPA Professional Institute. His current research interest and publications have focused on innovation and management control. Prior to academia, Dr. Klassen spent a number of years in senior positions with a Big 4 Global Accounting and Consulting firm. 